\title{
Detection Of The Coa Gene In Staphylococcus aureus From Different Sources By Polymerase Chain Reaction
}

\author{
Ahlam A Gharib , M.A. Adel Attia and M.M.Bendary \\ Department of Bacteriology, Mycology and Immunology, Fac. of Vet. Med., \\ Zagazig University
}

\section{ABSTRACT}

One hundred and ninety eight samples of human and animal sources from different areas in El-Sharkia Governorate were used in this study to isolate Staphylococcus species and to determine the presence of coagulase ( $\mathrm{coa}$ ) gene , a virulence gene detected in $S$. aureus (CoPS), by PCR. Primary isolation on mannitol salt agar, $\beta$ - haemolysis, tube coagulase test (TCT) and other biochemical characterization revealed $32.8 \%(65 / 198)$ of the total samples were infected with staphylococci, only 35 isolates were biotyped as coagulase-positive Staphylococci (Cops) and represented as 8 $(8.8 \%), 10(22.2 \%)$ and $17(26.9 \%)$ in milk, meat and human samples, respectively. Meanwhile, Coagulase-negative Staphylococci (CoNS) were obtained only from cows milk. Fifteen CoPS (5 milk samples, 4 meat products and 6 human samples) were subjected to analysis by PCR for detection of coa gene. The resulted amplicons were 648, 723, 812 and $913 \mathrm{bp}$. According to coa gene polymorphism, milk and meat isolates were grouped into 5 groups, while human isolates were grouped into 4 groups. It was noted that two of the strains, classified as coagulase negative by tube coagulase test, were found to be positive with PCR amplification of the gene which clearly emphasizes the use of molecular methods in detecting $S$. aureus. In conclusion, the coa amplification has been considered as a simple and accurate method for typing of S. aureus.

Key words: Mastitis. Caoagulase polymorphism. CoPS. CoNS. Food products.

INTRODUCTION

Staphylococcus aureus is considered a significant pathogen of animal and human. Economic importance to dairy industry due to staphylococcal infection results from subclinical mastitis accompanied with reduction in the milk quality and a loss in its production. In spite of increasing 
frequency of isolation of coagulase negative staphylococci (CoNS) from the bovine mammary glands, CoPS is recognized worldwide as a major pathogen causing subclinical intramammary infection in dairy cows (Turutoglu et al, 2005). S. aureus is the most common bacteria, followed by E.coli and $S$. agalactiae in subclinical mastitis cases, while E. coli is the most common bacteria detected in clinical mastitis cases, followed by S.aureus and S.agalactiae (Amin et al, 2011). S. aureus is a predominant colonizer of the skin. It is responsible for many different types of human infections. The predominant type of infection usually related to skin abscesses and can occur in the form of furuncles or carbuncles, but it rarely causes infection without a predisposing route of entry. Impetigo is a well known staphylococcal related infection which is characterized by honey-crusted lesions of the skin (Friedman and Ratard, 2007). S.aureus has a large repertoire of virulence factors, including structural and secreted products that play a role in pathogenesis (Defres et al, 2009). Staphylocoagulase is an extracellular protein that has traditionally been used to differentiate S.aureus from the less virulent staphylococci (CoNS). $S$. aureus secretes two clotting factors, coagulase $(\mathrm{Coa})$ and von Willebrand factor binding protein
(vWbp), the Coa and vWbp together are required for the formation of abscesses and promote the non proteolytic activation of prothrombin and cleavage of fibrinogen, reactions that are inhibited with specific antibody against each of these molecules. Coa and vWbp specific antibodies confer protection against abscess formation and $S$. aureus lethal bacteraemia, suggesting that coagulases function as protective antigens for a staphylococcal vaccine, so, coagulases may be used as vaccine antigens to elicit antibodies that protect humans against $S$. aureus infections (Cheng et al,2010) . Moreover, abscesses formation, bacterial persistence in host tissues, blood clotting of coagulase producing S.aureus enable the pathogen to cause lethal sepsis, disseminate as thromboembolic lesion and resist opsonophagocytic clearance by host immune cells. Preclinical evidence suggests that inactivation or neutralization of coagulase may prevent the pathogenesis of staphylococcal infection (Friedman and Ratard, 2007; Chadrakanth et al.,2010 and Mcadow et al.,2012). Rapid and accurate typing of Staphylococcus aureus is crucial to understand the transmission of this infectious organism. The traditional phenotypic methods have several drawbacks (Tenover et al ., 1994). Molecular typing can shorten or 
prevent an epidemic and reduce the number and cost of nosocomial infections. This typing can also clarify whether the strains from the environment, instruments, staff, or food are responsible for causing infection. In this way this helps to trace the source of infection or an outbreak, tracking the spread of infections and helps to take specific infection control measure (Hacek et al, 1999) . The coa gene amplification has been considered a simple and accurate method for typing of $S$. aureus isolated from distinct sources, the coagulase protein is an important virulence factor of $S$. aureus. Like spa, coa has a polymorphic repeat region that can be used for differentiating $S$. aureus isolates. The variable region of coa is comprised of $81 \mathrm{bp}$ tandem short sequence repeats (SSRs) (Van-Belkum et al, 1998) . The objective of this study was to detect the presence of $c o a$ gene in $S$. aureus from different sources by PCR amplification.

\section{MATERIALS AND METHODS Samples:}

One hundred and ninety eight samples of human and animal sources were collected from different areas in Sharkia Governorate in the period from January to May 2011. Samples of Human source (63) as blood (10), urine (12), C.S.F. (8), sputum (8), pericardial fluid (7), pus (10) and peritoneal fluid (8) were collected from different clinical cases of different ages administered to ultra laboratory and El Gamah hospital. Samples of animal source (135) were mastitic milk (90) collected from 4 farms (Abo-Mandor, Elsalhia, El hosania and Italian company farms) and random meat products (45) as minced meat (20), burger (15) and sausage (10) were collected from different sale markets. All samples were sent as soon as possible to laboratory of bacteriology, Faculty of Veterinary Medicine, Zagazig University and examined for staphylococci.

Isolation and identification of Staphylococcus species:

All samples from different sources were inoculated onto mannitol salt agar (Difco,USA.) and incubated for up to one week at $37^{\circ} \mathrm{C}$ and all developed colonies with grapes like shape under light microscope were inoculated into soft agar for culture preservation

(Difco,USA.).The distribution of the isolates according to growth onto MSA,oxidation fermentation ( OF ) test and bacitracin susceptibility was detected (Mackie and McCartney, 1996). The developed colonies onto MSA were subjected to tube coagulase test [TCT] (Gillespie, 1943) and for $\beta$ haemolysis onto blood agar to differentiate between the CoPS and CoNS. These isolates were further identified as $S$. aureus by API20S kits, commercial identification 
system (BioMerieux, 1992) and kept frozen at $-20{ }^{\circ} \mathrm{C}$ in nutrient broth with $3 \%$ glycerol until molecular tests were carried.

\section{DNA extraction:}

The bacterial genomic DNA was extracted from only $15 \mathrm{~S}$. aureus isolates (CoPS), using DNA extraction kits (Biofermentus).

\section{DNA amplification:}

The PCR for amplification of coa gene was performed in a total reaction volume of $25 \mu \mathrm{l}$ for one sample according to (Himabindu et al,2009) using PCR master mix (DreamTaq ${ }^{\mathrm{TM}}$ Green Master Mix (2X), Fermentas, Catalogue No. \#K1081., Lot: 00055548). It is a ready to use solution containing DreamTaq TM DNA polymerase, optimized DreamTaq TM Green buffer (2X), $4 \mathrm{mM} \quad \mathrm{MgCl}_{2}$ and dNTPs (dATP, dCTP, dGTP and dTTP, $0.4 \mathrm{mM}$ each). The sequence of primer used for amplification of coa gene (Himabindu et al, 2009) was

forward: 5'CGAGACCAAGATTCAACAA G 3' and Reverse: 5'AAAGAAAACCACTCACATC A 3'.

The PCR cycling protocol was applied as following: initial denaturation at $94^{\circ} \mathrm{C}$ for $5 \mathrm{~min}$, followed by 30 cycles of denaturation at $95^{\circ} \mathrm{C}$ for 30 second, annealing at $55^{\circ} \mathrm{C}$ for 45 second and extension at $72^{\circ} \mathrm{C}$ for $2 \mathrm{~min}$., followed by a final extension at $72^{\circ} \mathrm{C}$ for $7 \mathrm{~min}$.
Agarose gel electrophoresis and visualization of $P C R$ products:

$5 \mu 1$ of each amplicon was electrophoresed in $1.5 \%$ agrose gel (Sigma -USA) and visualised under U.V. transilluminator (Spectroline Model TC- 312 A, USA) (Sambrook et al,1989), then compared with the marker DNA ladder (100 bp, Gene Ruler ${ }^{\mathrm{TM}}$, Fermentas ).

\section{RESULTS}

\section{Culture findings:}

Staphylococci were isolated and identified by traditional phenotypic methods from $32.8 \%(65 / 198)$ of the samples represented 38,10 and 17 isolates from milk, meat products and human samples, respectively .

Only one isolate of micrococcus was obtained from milk samples. On MSA agar, yellow colonies showing mannitol fermentation were selected and divided into 2 groups based on the coagulase test and $\beta$-hemolysis.

CoPS were confirmed as golden yellow pigmented colonies, coagulase positive and $\beta$-haemolytic $53.8 \% \quad(35 / 65) \quad$ represented 8 (8.8\%), 10 (22.2\%) and 17 (26.9\%) from milk, meat and human samples, respectively.

Meat staphylococci isolates (10) recovered from meat products were distributed as following: (1 from minced meat, 4 from sausages and 5 from burger). Meanwhile, human 
staphylococci (17) were 3 from urine, 5 from pus, 3 from sputum, 2 from CSF,one from blood, 2 from pericardial fluid and 1 from peritoneal fluid).

CoPS were predominated in isolates of meat products and human origin (the percentage of coagulase positive was equal to the percentage of $\beta$-haemolytic organisms $100 \%$ ), meanwhile, in staphylococcal isolates of milk samples, the percentage of coagulase positive (21\%) (8/38) was less than that of $\beta$-haemolytic (26\%) (10/38), as two isolates were $\beta$-haemolytic but coagulase negative.

CoNS $46.2 \%$ (30/65) were isolated only from milk samples and could be confirmed by API 20-S. Biotyping of the isolates by analytical profile index (API20-S) revealed that all coagulase positive and $\beta$-haemolytic isolates were $S$. aureus, in addition to the two isolates of milk samples that were coagulase negative and $\beta$ haemolytic.

\section{PCR findings:}

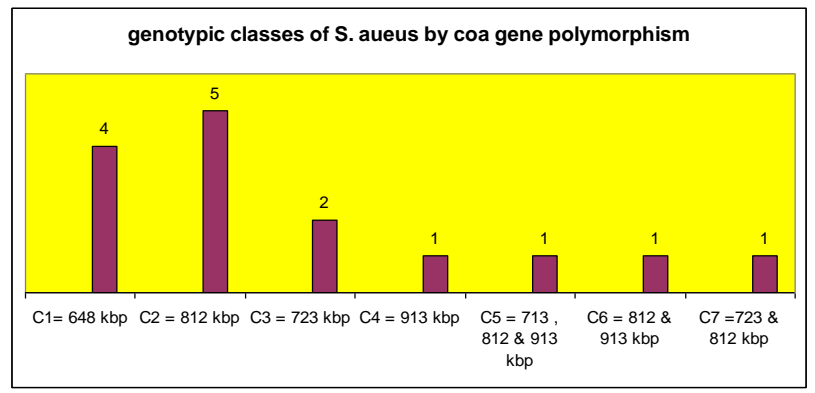

Most of isolates $80 \% \quad(12 / 15)$ produced a single band, with molecular sizes ranging from 648$913 \mathrm{bp}$, whereas 2(13.3\%) human isolates yielded 2 amplification products (double amplicons with molecular sizes of $723+812 \mathrm{bp}$ and $812+913$ bp) and only $1(6.6 \%)$ isolate of milk samples yielded 3 amplification products (triple amplicons with molecular sizes of $723+812+913$ bp) (Photos 1\&2, Figure 1).

The product 812 bp was the most frequent and accounted for $5 / 15$ $(33.3 \%)$ of the isolates, followed by 648 bp (26.6\%), 723 bp (13.3\%) and $913 \mathrm{bp}$ (6.6\%). According to coa gene polymorphism, the samples were grouped into 5 groups in (nine isolates of the milk and meat product) and 4 groups in (the six isolates of human subjects) (Figures 2\& 3). The two isolates from milk that were $\beta$-haemolytic and negative tube coagulase test, gave specific amplicon by coa gene amplification.
Fig.1 Genotypic classes of S.aureus by coa gene polymorphism. 

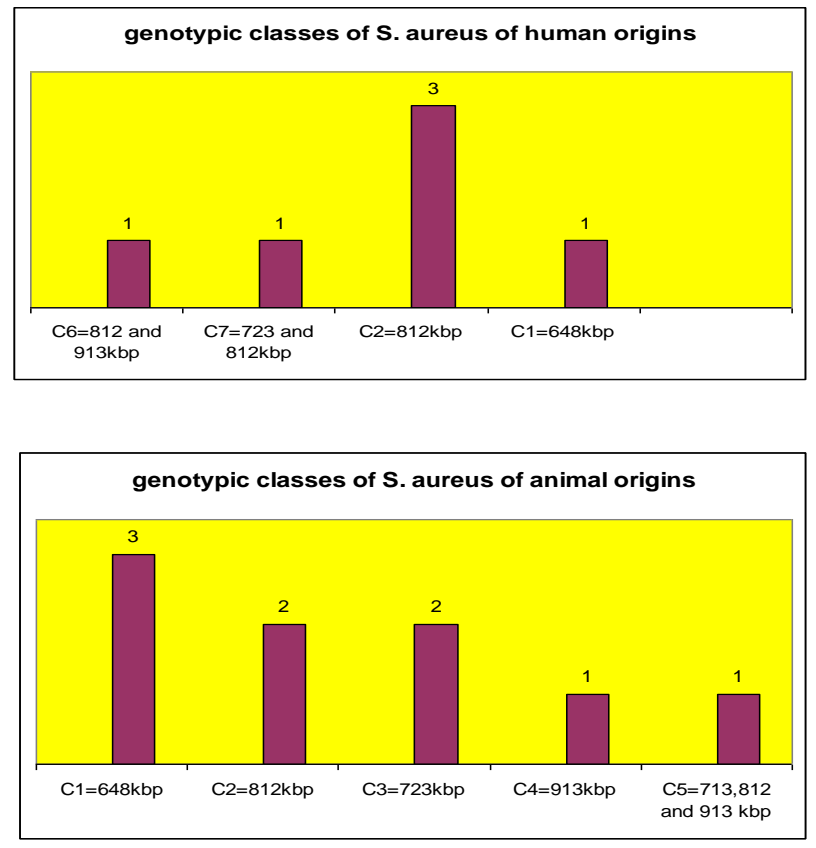

Fig. 3 Genotypic classes of

S. aureus of animal origins.

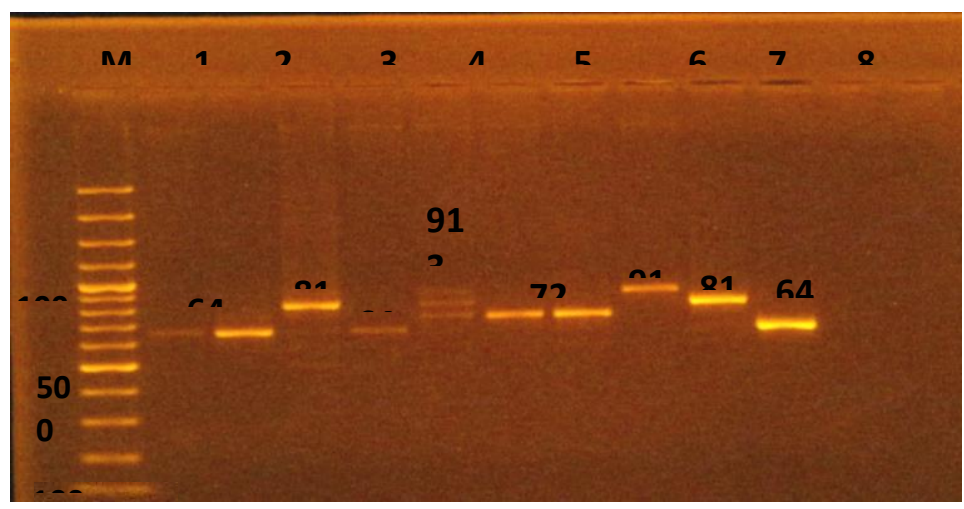

Photo 1: Coa gene polymorphism for S. aureus isolates of milk and meat products.

Lan 1 : +ve control obtained from central diagnostic and research lab. KafrEl -Sheikh university, Lan 2 (15M): with amplicon 648 bp, Lan 3 (18M): with amplicon 812 bp, Lan 4 (28M): with amplicon 648 bp, Lan 5 (139M): 


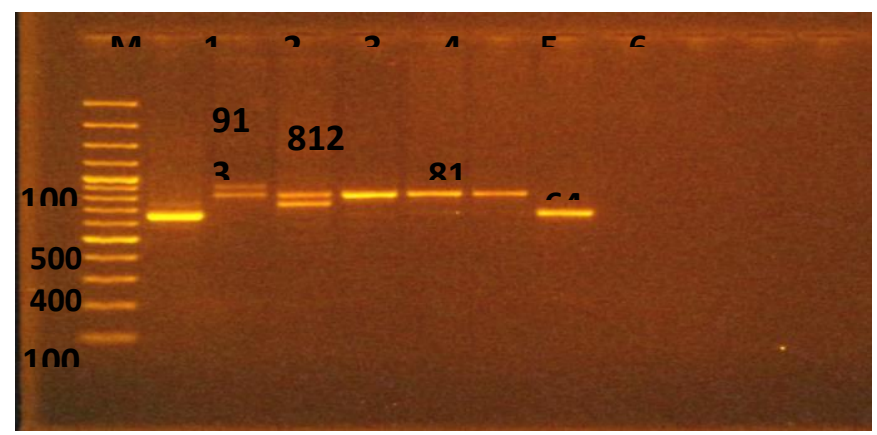

Photo 2: Coa gene polymorphism for S. aureus isolates of human subjects.

Lan 1: +ve control obtained from central diagnostic and research lab. KafrEl -Sheikh university, Lan 2 (206Pu) : with

\section{DISCUSSION}

Molecular typing of microorganisms is now recognized as an essential component of infection control program. These molecular techniques are effective in tracking the spread of nosocomial infections and planning the activities of the infection control program . Production of coagulase is an important phenotypic feature used worldwide for the identification of Staphylococcus aureus (Goh et al,1992). The coa gene amplification has been considered as a simple and accurate method for typing of Staphylococcus aureus.

In this study, $S$. aureus was recovered from different human and animal sources, phenotypically and genotypically identified. Seven coa PCR types and 9 groups patterns were detected, which indicated considerable heterogeneity in the coa gene of $S$. aureus in the studied samples. Until recently, single and also double banded coa PCR products were reported in $S$. aureus strains derived from bovine mastitis in Brazil (Da Silva and Da Silva 2005). Double-banded amplification product was detected only in one coa positive isolate (Goh et al, 1992), which explained the presence of double-banded amplification products with different allelic forms of the coa gene.

Our amplification of DNA of $S$. aureus isolates obtained from human and animal sources revealed four amplicons $(723,812,648$ and 913 bp), These amplicons could classify the isolates into 4 groups (human) or 5groups (animal) . 
Similar results were obtained by Himabindu et al (2009) who showed that the sizes of PCR products obtained after amplification of S.aureus of human subjects rang from $650-1000 \mathrm{bps}$. Ishino et al.(2007) classified 678 S.aureus isolates of human subjects into 8 classes and the sizes of the PCR products of coa gene ranged from 350 to $917 \mathrm{bp}$ in increments of $81 \mathrm{bp}$, In addition, Schlegelova et al (2003) reported the size of coa gene PCR product of S.aureus isolates from dairy cow and human $650-1050 \mathrm{bp}$, this result gave 4 classes at $650,730,810$ and 1050 bp ;class 730 bp was the most common class between the isolates. Also Hookey et al (1999) detected the size of coagulase PCR product of $S$. aureus isolates from human subjects that was either 660,603 or $547 \mathrm{bp}$. Furthermore, Reinoso et al (2008) detected that PCR amplification of the coa gene of $S$. aureus isolated from human, bovine subclinical mastitis and food samples which- yielded seven different coa types from $45 \mathrm{~S}$. aureus strains with amplicon sizes ranging from 400 to $1000 \mathrm{bp}$. Seven (42\%) human infection strains had coa polymorphic regions with an amplicon of $700 \mathrm{bp}$, indicating the presence of five repeats, Six (40\%) of the bovine strains showed an amplicon of $900 \mathrm{bp}$, indicating the presence of seven repeats and four
(50\%) strains from food samples showed four repeats.

Also, Da Silva and Da Silva (2005) showed that the amplification of the coa gene from the 64 S. aureus isolated from cow with mastitis produces 27 different PCRproducts; which ranged from approximately 579 to approximately 1442 bp. Sizes 790, 759, 725 and 579 bp were the most frequent . Two CoNS isolates showed similarity to $S$. aureus, and were reclassified as CoPS species by API20s and coa gene detection with 648 and 812 bp amplicons. The same results were obtained by Himabindu et al (2009) and De Moura et al (2012) who noted that two of the strains that were classified as coagulase negative by tube coagulase test were found to be positive with PCR amplification of the gene. So the correct amplification of all isolates by PCR not only confirm the results of biochemical tests but is more accurate . Coagulase production is the principal criterion used by the clinical microbiology laboratory for the identification of Staphylococcus aureus . Numerous allelic forms of $S$. aureus coagulase exist, with each isolate producing one or more of these enzyme variants (Landolo, 1990) .

In conclusion, this study has shown that infection in the studied samples was caused by $S$. aureus strains harboring more than one coa 
genotype and that only one genotypes predominated. However, further studies using a RFLP technique and nucleotide sequencing methods on a large collection of strains could be conducted to determine the common characteristics of the predominant strains.

\section{REFERENCES}

Amin, A. S., Hamouda R.H. and Abdel-All A.A., 2011. PCR Assays for Detecting Major Pathogens of Mastitis in Milk Samples World. Journal of Dairy and Food Sciences, 6 (2)pp: 199-206.

BioMerieux, S. A., 1992. Analytical profile index. BioMerieux Sa au capital de 45068 400 F/ imprime en France/ RCS Lyon B 673620399.

Chandrakanth, K., Virupakshaiah D.B.M.,Gavimath C.,Udaykumar M. and Kangralkar V.A., 2010. Comparative genomics of Staphylococcus aureus coagulase gene - Journal of Advanced Bioinformatics Applications and Research, 1(1pp: 31-36.

Cheng, A. G.,Mcadow M.,Kim H.K.,Bae T.,Missiakas D.M. and Schneewind O., 2010. Contribution of coagulases towards Staphylococcus aureus disease and protective immunity . Plos pathogen, 6 (8)pp: 1-17.

Da Silva, E. R. And Da Silva N., 2005. Coagulase gene typing of Staphylococcus aureus isolated from cows with mastitis in southeastern Brazil. Canadian Journal of Veterinary Research, 69,pp: 260-264

Defres, S.,Marwick C. and Nathwani D., 2009. MRSA as a cause of lung infection including airway infection, community acquired pneumonia and hospitalacquired pneumonia. European Respiratory Journal, 34(6)pp: 14701476.

De Moura, T. M.,Campos F. S., Azevedo P. A., Van Der Sand S.T., Franco A. C., Frazzon J. and Frazzon A. P. G., 2012.Prevalence of enterotoxin-encoding genes and antimicrobial resistance in coagulase-negative and coagulasepositive Staphylococcus isolates from black pudding] Revista da Sociedade Brasileira de Medicina Tropical, 45(5)pp:579-585

Friedman, D. A. and Ratard R. C., 2007. The louisiana antibiogram. In vitro antibiotic sensitivity patterns 2003-2004: Louisiana State University School of Public Health and Louisiana Department of Health.

Gillespie, E. B., 1943. The routine used of the coagulase test for staphylococci. Monthly Bulletin of the Emergency Public Health Laboratory Sevice, 2,pp19-22.

Goh, H. S., Byrne K. S., Zhang J. L. and Chow A. W., 1992. Molecular typing of Staphylococcus aureus on the basis of coagulase gene Polymorphisms, Journal of 
Clinical Microbiology,30 (7),pp : 1642-1645.

Hacek, D. M., Suriano T., Noskin G. A., Kruszynski J., Reisberg B. and Peterson L.R., 1999. Medical and economic benefit of a comprehensive infection control program that includes routine determination of microbial clonality. American Journal of Clinical Pathology, 111,pp: 647654.

Himabindu, M., Muthamilselvan S. D., Bishi D. K. and Verma R. S., 2009. Molecular analysis of coagulase gene polymorphism in clinical isolates of methicilin resistant Staphylococcus aureus by restriction fragment length Polymorphism based genotyping. American Journal of Infectious Diseases, 5 (2),pp: 170-176.

Hookey, J. V., Edwards V., Cookson B.D. and Richardson J. F., 1999. PCR-RFLP analysis of the coagulase gene of Staphylococcus aureus: Application to the differentiation of epidemic and sporadic methicillin-resistant strains. Journal of Hospital Infection, 42,pp: 205-212.

Ishino, K., Tsuchizaki N., Ishikawa J. and Hotta K., 2007. Usefulness of PCR-restriction fragment length polymorphism typing of the coagulase gene to discriminate arbekacin-resistant methicillin-resistant Staphylococcus aureus Strains. Journal Clinical Microbiology, 45 (2) pp: 607-609
Landolo, J. J., 1990. The genetics of staphylococcal toxins and virulence factors. In. Ed . Gunsalus I. C, Academic Press, New York,pp: 399-426.

Mackie, T. J. and McCartney J. E., 1996. Practical Medical Microbiology. international, $14^{\text {th }}$ ed., Chapter 11. U.S.A.Churchill Livengtone.

Mcadow, M., Missiakas D. M. and Schneewind O., 2012. S.aureus secretes coagulase and von willebrand factoer binding protein to modify the coagulation cascade and establish host infections. Journal of Innate immune, 4(2)pp:141-148.

Reinoso, B. E., El-Sayed A., Lämmler C., Bognia C. and ZschÖck M., 2008. Genotyping of Staphylococcus aureus isolated from humans, bovine subclinical mastitis and food samples in Argentina . Microbiological Research, 163 pp: 314-322.

Sambrook, J., Fritsch E. F. and Maniatis T., 1989. Molecular cloning: A laboratory manual, $2^{\text {nd }}$ Ed. Cold Spring Harbor Laboratory Press, New York. pp:2001 - 2344.

Schlegelova, J., Dendis M., Benedik J., Babak V. and Rysanek D., 2003. Staphylococcus aureus isolates from dairy cow and human on a farm differ in coagulase genotype. Veterinary Microbiology Journal, 92,pp: 327-334

Tenover, F. C., Arbeit R., Archer G., Biddle J., Byrne S., Goering 
R., Hancock G., Hebert G. A., tube coagulase test. Bulletin of the Hill B. and Hollis R., 1994. Veterinary Institute in Pulawy, 49 Comparison of traditional and ,pp: 419-422.

molecular methods of typing isolates of Staphylococcus aureus. Journal of Clinical Microbiology, 32(2) pp: 407-415.

Turutoglu, H., Tasci F. and Ercelik S., 2005. Detection of staphylococcus aureus in milk by

Van -Belkum, A., Scherer S., Van-Alphen L. and Verbrugh $H$., (1998). Short-sequence DNA repeats in prokaryotic genomes . Microbiology and Molecular Biology Reviews, pp : 275-293.

الملخص العربى

تحديد جين التلزن الدموى فى الميكروب العنقودى المعزول من مصادر مختلفة

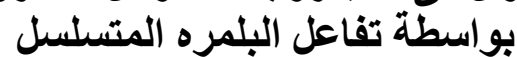

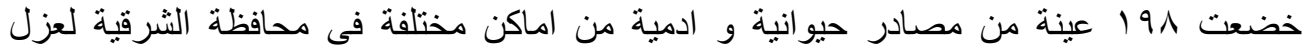

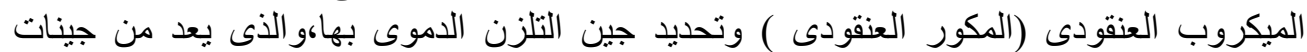

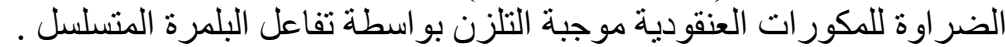

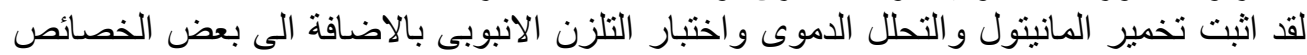

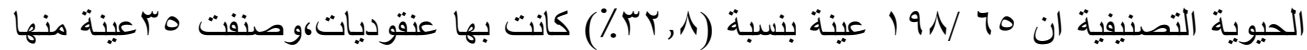

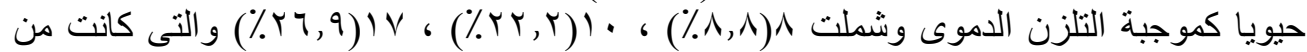

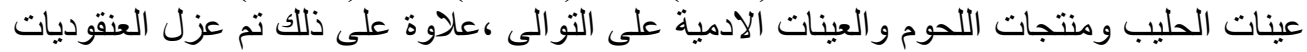

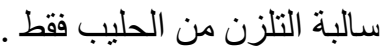

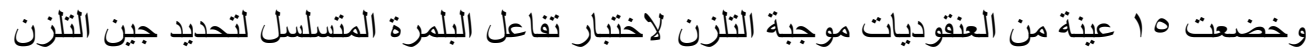

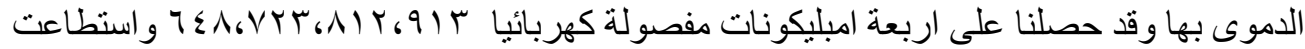

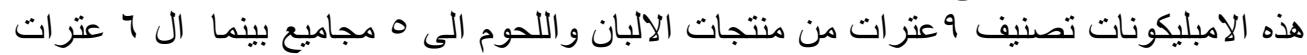

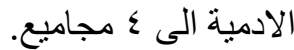
لوحظ ان عترتان من العنقوديات قد صنفتا سالبة التلزن (بواسطة اختبار التلزن الانبوبى) لكنها

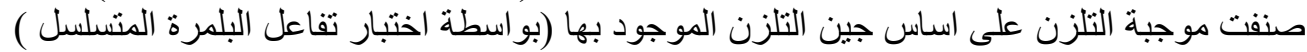

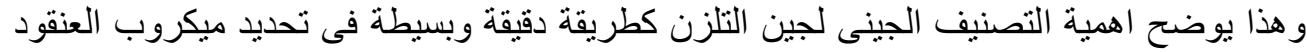

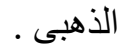

